\title{
Actaea grimaldii, a new species of reef crab from Papua New Guinea (Crustacea, Brachyura, Xanthidae)
}

\author{
Peter K.L. $\mathrm{NG}^{1}$ \& Philippe BOUCHET ${ }^{2}$ \\ ${ }^{1}$ Lee Kong Chian Natural History Museum, National University of Singapore, Kent Ridge, \\ Singapore 119260, Republic of Singapore. \\ Email: peterng@nus.edu.sg (corresponding author) \\ ${ }^{2}$ Institut de Systématique, Évolution, Biodiversité ISYEB, UMR 7205 - CNRS, MNHN, UPMC, EPHE, \\ Muséum national d'Histoire naturelle, Sorbonne Universités, \\ 57 rue Cuvier, CP 51, F-75252, Paris, France. \\ pbouchet@,mnhn.fr \\ ${ }^{1}$ urn:lsid:zoobank.org:author:8ACB5B5C-7DC3-43A7-82E4-420AD0FF7377 \\ ${ }^{2}$ urn:lsid:zoobank.org:author:FC9098A4-8374-4A9A-AD34-475E3AAF963A
}

\begin{abstract}
A new species of xanthid crab, Actaea grimaldii, is described from the coral reefs of Papua New Guinea. This species has a distinctive red and white coloration and is closest to Actaea spinosissima Borradaile, 1902, from the Indian Ocean. However, the new species can be distinguished by the arrangement of spines on the carapace, chelipeds and ambulatory legs, and the structure of the male gonopods. Actaea grimaldii sp. nov. has also been confused with A. polyacantha (Heller, 1861), but differs markedly in the carapace armature.
\end{abstract}

Keywords. Crustacea, Xanthidae, Papua New Guinea, Actaea, new species.

Ng P.K.L. \& Bouchet P. 2015. Actaea grimaldii, a new species of reef crab from Papua New Guinea (Crustacea, Brachyura, Xanthidae). European Journal of Taxonomy 140: 1-18. http://dx.doi.org/10.5852/ejt.2015.140

\section{Introduction}

In the 1970-1990s, extensive marine biology field work was carried out on the north coast of Papua New Guinea: at Laing Island, in Hansa Bay, at King Leopold III Biological Station, and in the Madang Lagoon, at a facility run by the Christensen Foundation. Several authors (e.g., Gosliner 1992; Thomas 1996) highlighted the exceptionally high species richness of Madang Lagoon, which became a famous place in marine biodiversity lore. Both King Leopold III Biological Station and the Christensen Foundation facility ceased operations in the mid-1990s, and, as a result, marine biologists essentially stopped research activities on the north coast of Papua New Guinea. However, in 2012 a large expedition, under the "Our Planet Reviewed" programme, was hosted on the campus of the Divine Word University in Madang. A new wave of novel marine species descriptions (e.g., Fricke 2014; Rubio \& Rolán 2014; Summers et al. 2014; Ng \& Anker 2014; Meyer-Wachsmuth et al. 2014; Macpherson \& Robainas-Barcia 2015) was generated by this multinational expedition which lasted two months and involved 110 participants. Many more reports await publication. Between November 30 and December 2, 2012, the expedition was 
visited by Prince Albert II of Monaco, whose Foundation had made the expedition possible. During his visit, the Prince was presented with a species of xanthid crab that, pending confirmation then, appeared new to science. Its colour pattern was similar to the colours of the armorial of the Grimaldi family and, with the Prince's approval, we offered to name the species after his family if it was confirmed to be new. The purpose of the present paper is to describe this new species of Actaea De Haan, 1833.

Actaea (type species Cancer granulatus Audouin, 1826; see Guinot \& Cleva 2009) is a xanthid genus typically associated with tropical coral reefs and currently containing 31 species (updated from $\mathrm{Ng}$ et al. 2008). The genus has been studied by Odhner (1925), Guinot $(1968,1969,1976)$ and Serène (1984) (see also Guinot \& Low 2010). However, many Actaea species are not well known, and a revision of Actaea s. str. is needed. One poorly known species is Actaea spinosissima Borradaile, 1902, originally described from the Indian Ocean. This species has also been reported from Australia and the Moluccas in eastern Indonesia by Odhner (1925) and Serène (1984), respectively. Examination of the type of $A$. spinosissima shows that a series of specimens from Papua New Guinea, as well as Serène's (1984) specimen, should be referred to a new species, here named $A$. grimaldii.

\section{Material and methods}

Material examined is deposited in:

- Muséum national d'Histoire naturelle, Paris, France (MNHN);

- Zoology Museum of Cambridge University, United Kingdom (CUMZ);

- Zoological Reference Collection of the Lee Kong Chian Natural History Museum (ex Raffles Museum of Biodiversity Research), National University of Singapore (ZRC).

The abbreviations G1 and G2 refer to the male first and second gonopods, respectively. Measurements provided (in millimetres) are of the maximum carapace width and length, respectively. The terminology for the carapace regions follows that proposed by Dana (1852) (see also Serène 1984: fig. C).

\section{Results}

Infraorder Brachyura Latreille, 1802

Superfamily Xanthoidea MacLeay, 1838

Family Xanthidae MacLeay, 1838

Subfamily Actaeinae Alcock, 1898

Genus Actaea De Haan, 1833

\section{Remarks}

Although the subfamily Actaeinae has been well studied by many authors, one name that was missed by most revisors is Actaeodius Klunzinger, 1913. For instance, the name is not listed in the revisionary studies and compilations by Serène (1984) and $\mathrm{Ng}$ et al. (2008). Klunzinger (1913: 231) established Actaeodius (as "Actäodius") when discussing the taxonomy of Actaea fragifera (White, 1848) and A. polyacantha (Heller, 1861). He decided that these names were synonyms and described and illustrated the species as "Actäodius fragifer". Guinot (1976: 236-237) followed and treated Klunzinger's "Actäodius fragifer" as a synonym of Actaea polyacantha. The status of the genus, however, has not been discussed. Although Klunzinger (1913) did not specifically state which was the type species of Actaeodius, his synonymy of the two treated species means that Chlorodius fragifer White, 1848 is the type species of the genus by monotypy. Currently, the two species are regarded as distinct species of Actaea s. str. (see Odhner 1925; Guinot 1976; Ng et al. 2008). 


\section{Actaea grimaldii sp. nov. urn:lsid:zoobank.org:act:A736C0FE-D2B4-4256-AB85-4370386B0231}

Figs $1-5$

Actaea peronii var. squamosa - Calman 1900: 10 (not Actaea squamosa Henderson, 1893). Actaea spinosissima - Odhner 1925: 59 (part). — Serène 1984: 115, pl. 14F. — Davie 2002: 511 (not Actaea spinosissima Borradaile, 1902).

\section{Diagnosis}

Anterior surfaces of carapace regions $(1 \mathrm{M}, 2 \mathrm{M}, 3 \mathrm{M}, 2 \mathrm{~L}, 5 \mathrm{~L})$ covered with numerous short sharp spines and sharp tubercles of varying sizes, $2 \mathrm{M}$ and $2 \mathrm{~L}$ surface gently convex, not distinctly inflated in frontal view, 2M separated by median longitudinal groove anteriorly, 4M lunate, with sharp granules; 1P flattened, divided into many smaller regions by shallow grooves, with distinct transverse groove on anterior third, confluent with series of flattened granules on 3R, 2R and 1R (Figs 1, 2A, 3A, 4A); frontal margins lined by sharp granules, $1 \mathrm{~F}$ and $2 \mathrm{~F}$ with many sharp spines which project anteriorly, hiding frontal margin from dorsal view (Figs 1, 2A-B, 3A-B, 4A); anterolateral margin with 4 spines (excluding external orbital spine), each with smaller spine or spines basal to it on sub-branchial surface (Figs 1, 2A, 3A, 4A); suborbital and subhepatic regions covered with numerous small, sharp granules (Figs 2B, 3B); third maxilliped with outer surfaces pitted (Fig. 5A); outer surfaces of chelipeds with numerous sharp spines and sharp tubercles, with small, sharp granules interspersed, carpus ovate, inner angle with several short, slightly curved spines, outer surface of chela with strong spines, inner surface of chela with median spine and several smaller sharp tubercles and granules (Figs 1, 2A, C-D, 3A, $\mathrm{C}-\mathrm{D})$; ambulatory legs short, outer surfaces of merus, carpus and propodus covered with sharp tubercles or granules, dorsal margins of merus, carpus and dactylus with numerous sharp spines, ventral margin of dactylus with subterminal tubercle, with scattered long, simple setae, some of which extend beyond tip of dactylus (Figs 1, 2A, 3A, 4C); thoracic sternum with surface distinctly pitted (Figs 1B, 5B); male abdomen longitudinally narrow, surfaces of sternites 1-3 pitted (Fig. 5C); G1 elongate, gently sinuous, distal part curves upwards (Fig. 5D-F).

\section{Etymology}

The species name is in honour of His Serene Highness Albert II, Prince of Monaco, patron of the PAPUA NIUGINI Expedition and several other biodiversity expeditions of the "Our Planet Reviewed" programme conducted by MNHN and Pro-Natura International. The red and white colour pattern of the new species also alludes to the colours associated with the House of Grimaldi.

\section{Type material}

\section{Holotype}

PAPUA NEW GUINEA: Madang District, Expedition PAPUA NIUGINI, stn PB35, outer slope, south

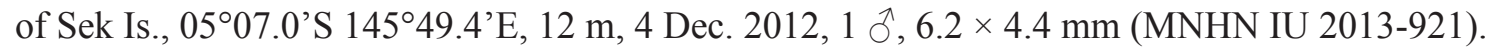

\section{Paratypes}

PAPUA NEW GUINEA: same data as holotype, 1 त, $5.1 \times 3.8 \mathrm{~mm}($ ZRC, ex MNHN IU 2013-920); Madang District, Expedition PAPUA NIUGINI, stn PR17, west of Kranket Is., $05^{\circ} 11.8^{\prime}$ S $145^{\circ} 48.8^{\prime}$ E, 15 m, 11 Nov. 2012, 1 + , $10.2 \times 7.8$ mm (ZRC, ex MNHN IU 2013-1245); Expedition PAPUA NIUGINI, stn PR05, Kranket Is., 05¹1.3'S 14549.6'E, 7 Nov. 2012, 1 ㅇ, 8.5 × 6.2 mm (MNHN IU 2013-222);

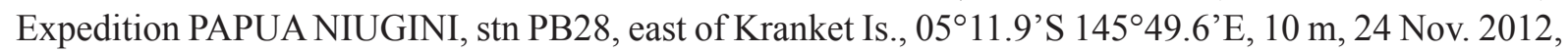
1 young +, $6.7 \times 4.9 \mathrm{~mm}(\mathrm{MNHN}$ IU 2013-759). 


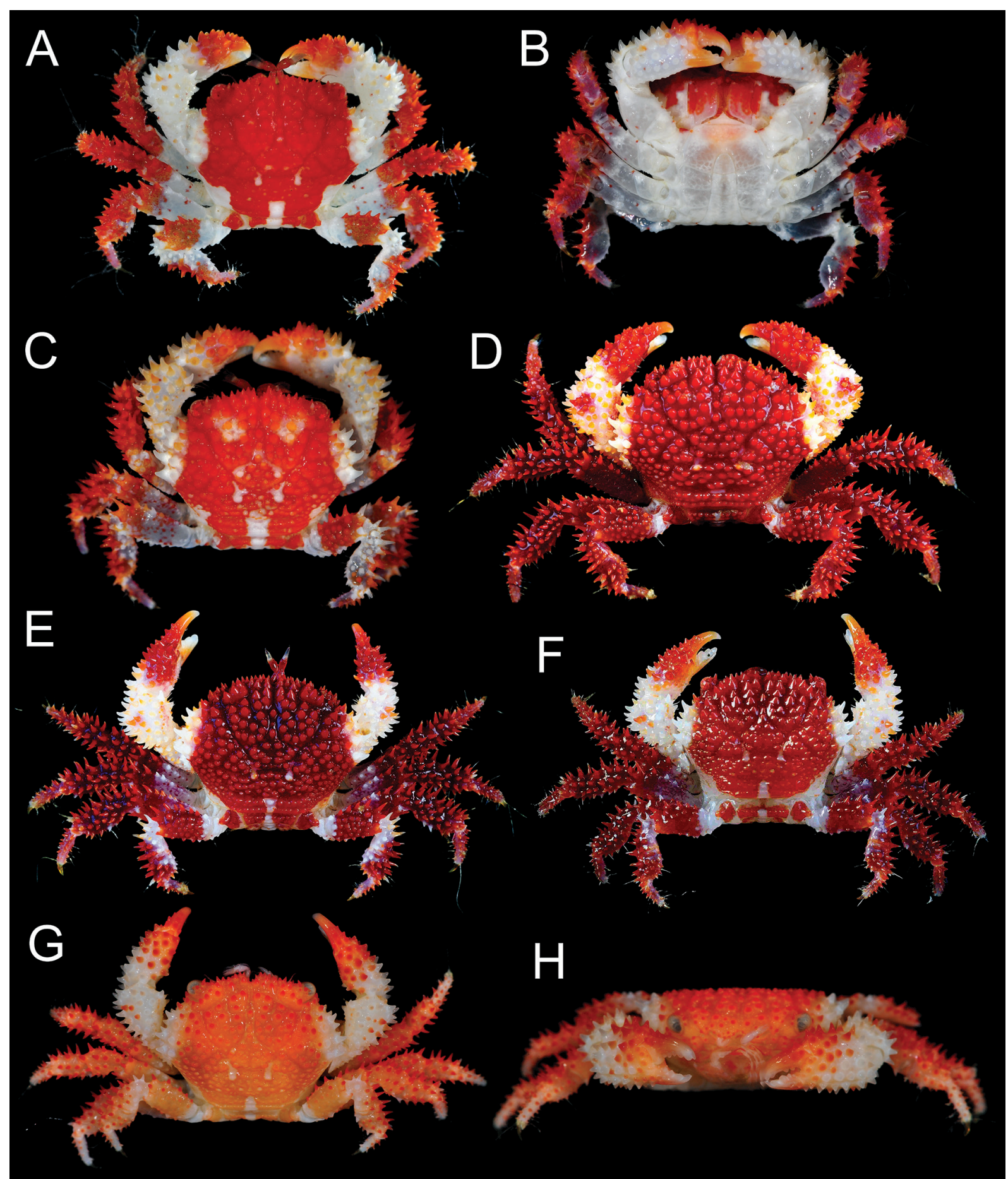

Fig. 1. Actaea grimaldii sp. nov., Papua New Guinea, colours in life. A-B. Paratype, $\widehat{\jmath}, 5.1 \times 3.8 \mathrm{~mm}$ (ZRC, ex MNHN IU 2013-920). C. Holotype, ô, $6.2 \times 4.4$ mm (MNHN IU 2013-921). D. Paratype,, , $10.2 \times 7.8 \mathrm{~mm}$ (ZRC, ex MNHN IU 2013-1245). E. Paratype,, , $8.5 \times 6.2 \mathrm{~mm}$ (MNHN IU 2013-222). F. Paratype,, , $6.7 \times 4.9 \mathrm{~mm}$ (MNHN IU 2013-759). G-H. Paratype,, , $6.4 \times 4.9 \mathrm{~mm}($ ZRC, ex MNHN IU 2013-1255). A-G, dorsal views of habitus; B, ventral view of habitus; $H$, frontal view of habitus. 


\section{Comparative material}

Actaea spinosissima Borradaile, 1902

MALDIVES: Mahlos Atoll, 23 fathoms, J.S. Gardiner coll., holotype, $\widehat{\jmath}, 5.1 \times 3.4 \mathrm{~mm}$ (juvenile, no gonopods) (CUMZ I.63106).

BRITISH INDIAN OCEAN TERRITORY: Great Chagos Bank, stn CH0666, outer reef, among dead branching coral heads, 10 m, Brothers Island, C. Head \& H. Koldewey coll., 28 Feb. 2013, 1 ô, $8.9 \times$ $6.6 \mathrm{~mm}(\mathrm{ZRC})$.

\section{Actaea polyacantha (Heller, 1861)}

GUAM: southwest of Orote Peninsula, G. Paulay coll., 15-18 Apr. 2000, 1 q (ZRC 2000.731).

PAPUA NEW GUINEA: Expedition PAPUA NIUGINI, stn PB17, outer slope, Sek Is., $05^{\circ} 04.9^{\prime} \mathrm{S}$

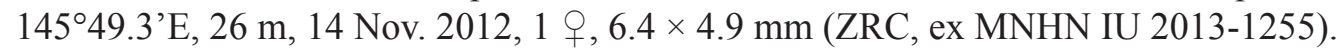

Actaea peronii (H. Milne Edwards, 1834)

AUSTRALIA: New South Wales, M. Ward coll., 2 q $q$ (ZRC 1969.12.27.3-4).

\section{Description}

Regions well demarcated, separated by distinct grooves, anterior surfaces (notably 1M, 2M, 3M, 2L, 5L) covered with numerous spines and sharp tubercles of varying sizes; $2 \mathrm{M}$ and $2 \mathrm{~L}$ surface gently convex, does not appear inflated in frontal view; $2 \mathrm{M}$ separated by median longitudinal groove anteriorly; $3 \mathrm{M}$ subtriangular, with sharp spines; $4 \mathrm{M}$ lunate, with sharp granules; $1 \mathrm{P}$ flattened, divided into many smaller regions by shallow grooves, with distinct transverse groove on anterior third, confluent with series of flattened granules on 3R, 2R and 1R; $2 \mathrm{O}$ transversely narrow, low; $2 \mathrm{P}$ raised, surface rounded (Figs 1, 2A, 3A, 4A). Frontal margin bilobate, lobes separated by broad, U-shaped cleft; margins lined by sharp granules; $1 \mathrm{~F}$ and $2 \mathrm{~F}$ with many sharp spines which project anteriorly, hiding frontal margin from dorsal view (Figs 1, 2A-B, 3A-B, 4A). Supraorbital margin with 3 distinct spines; orbit short, ovate; eye completely filling orbit; peduncle short, stout, with several dorsal granules; cornea large, with granule basally (Figs 2A-B, 3A-B, 4A-B). Anterolateral margin arcuate, with 4 spines (excluding external orbital spine), each with smaller basal spine or spines on sub-branchial surface; posterolateral margin gently concave, surfaces covered with small, flattened granules; posterior carapace gently sinuous, lined with small, flattened granules (Figs 1, 2A, 3A, 4A).

Suborbital margin with 5 or 6 small spines; suborbital and subhepatic regions covered with numerous small, sharp granules; pterygostomian region almost smooth (Figs 1H, 2B, 3B). Antennules folding laterally (Figs 2B, 3B). Antenna with basal article quadrate, with 1 large and 1 small, sharp granule, mobile; flagellum short, at base of orbital hiatus (Figs 2B, 3B). Epistome transversely rectangular; anterior margin granulated; posterior margin with prominent median triangle, lateral margins sinuous (Figs 2B, 3B).

Third maxilliped relatively short; outer surfaces pitted; ischium subrectangular, with shallow but distinct submedian sulcus, inner margin dentate; merus quadrate, distolateral angle not distinctly auricular; exopod stout, distal end reaching to distolateral edge of merus, flagellum elongate, as wide as merus (Fig. 5A).

Chelipeds slightly asymmetrical; outer surfaces with numerous sharp spines and sharp tubercles, with small, sharp granules interspersed; inner and outer surfaces with scattered short, simple setae (Figs 1, 2A, C-D, 3A, C-D). Basis-ischium lined with small granules. Merus short, rounded; dorso-distal spine largest. Carpus ovate, inner angle with several short, curved spines (Figs 1, 2A, 3A). Chelae short, stout, palm longer than fingers, not pigmented black or dark brown; inner surface with median spine and several smaller sharp tubercles and granules (Figs 2C-D, 3C-D). Pollex with 2 low, longitudinal ridges, 1 submedian groove; cutting edge with 3 or 4 large, blade-like teeth; tip subspatuliform (Figs 2C-D, 


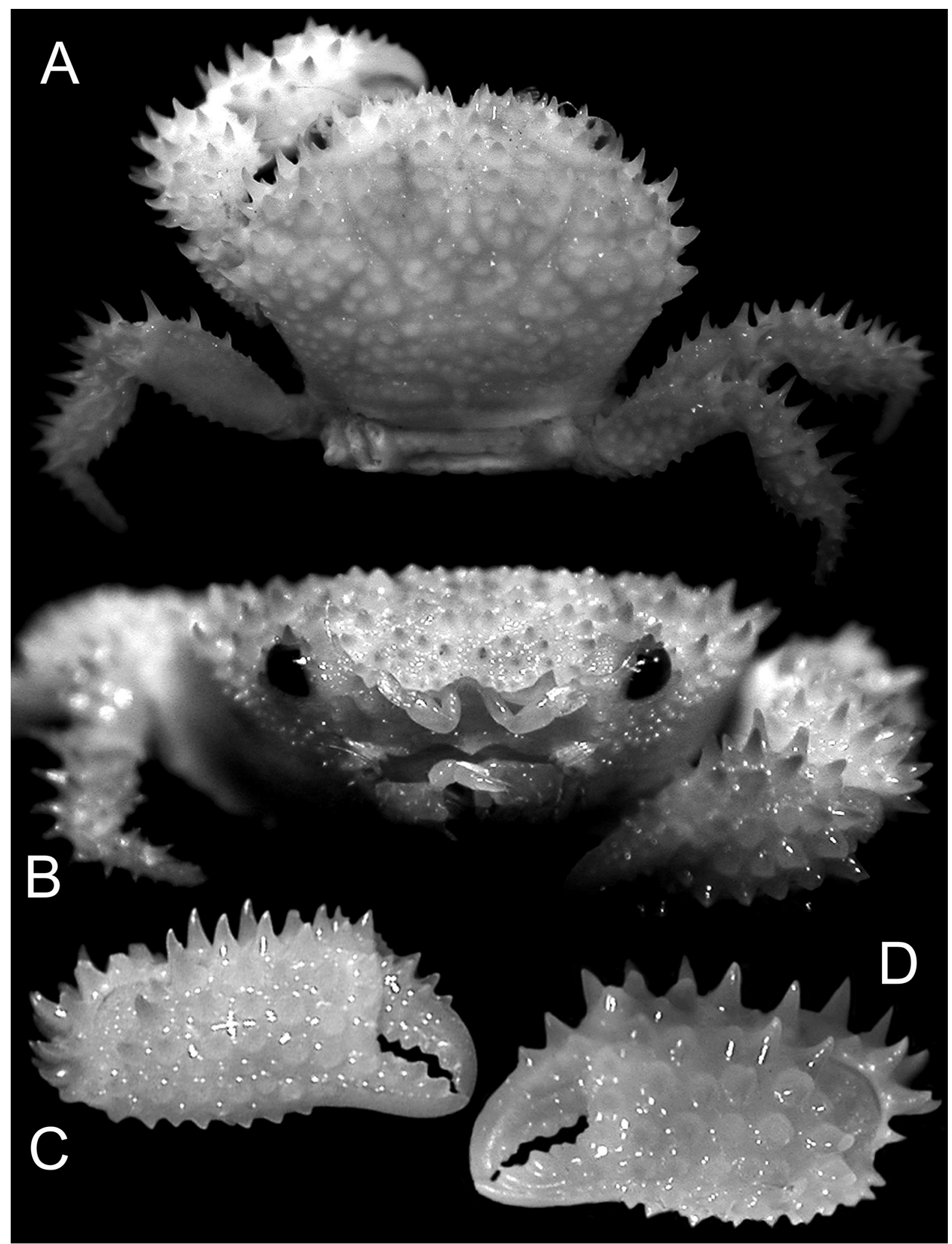

Fig. 2. Actaea grimaldii sp. nov., holotype, ô, $6.2 \times 4.4 \mathrm{~mm}$ (MNHN IU 2013-921), Papua New Guinea. A. Dorsal view of habitus. B. Frontal view of carapace. C. Outer view of right chela. D. Outer view of left chela. 


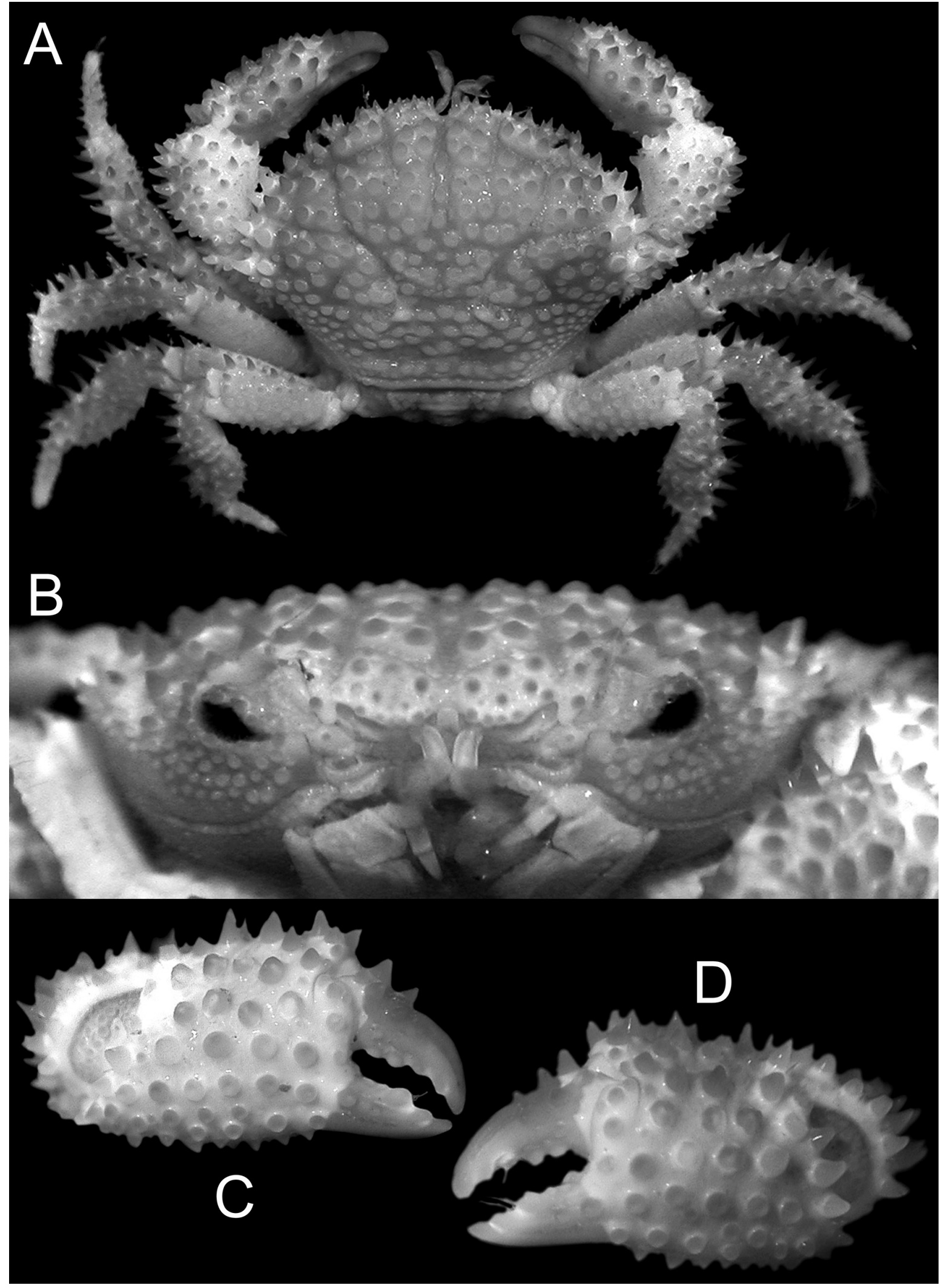

Fig. 3. Actaea grimaldii sp. nov., paratype,, , $10.2 \times 7.8 \mathrm{~mm}$ (ZRC, ex MNHN IU 2013-1245), Papua New Guinea. A. Dorsal view of habitus. B. Frontal view of carapace. C. Outer view of right chela. D. Outer view of left chela. 

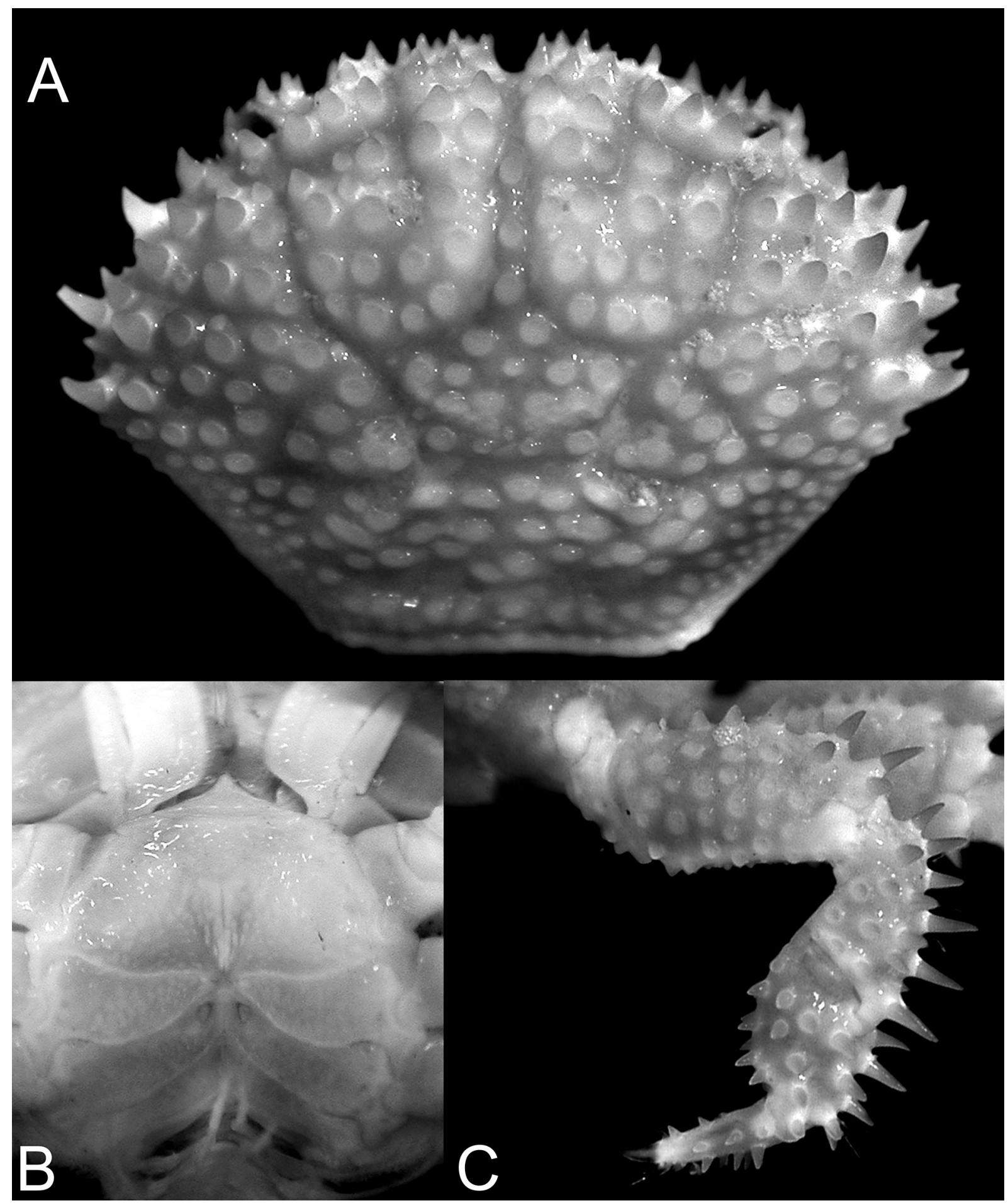

Fig. 4. Actaea grimaldii sp. nov., paratype,, , $10.2 \times 7.8 \mathrm{~mm}$ (ZRC, ex MNHN IU 2013-1245), Papua New Guinea. A. Dorsal view of carapace. B. Thoracic sternum showing vulvae. C. Right fourth ambulatory leg. 


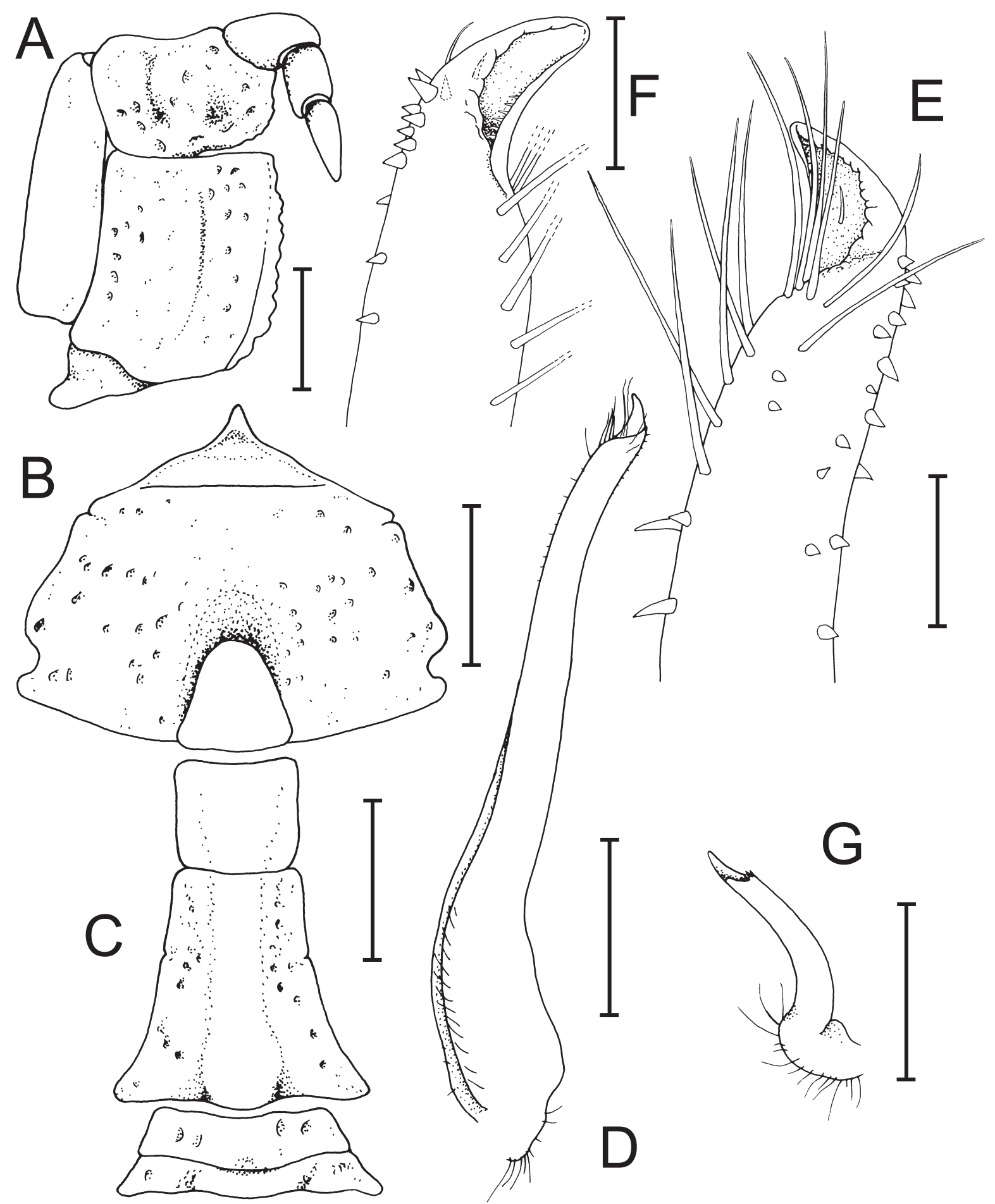

Fig. 5. Actaea grimaldii sp. nov., holotype, $\widehat{\jmath}, 6.2 \times 4.4 \mathrm{~mm}$ (MNHN IU 2013-921), Papua New Guinea. A. Right third maxilliped (setae not drawn). B. Anterior thoracic sternum (sternites 1-4) and telson. C. Abdominal somites 1-6. D. Ventral view of left G1. E. Ventral view of distal part of left G1. F. Dorsal view of distal part of left G1. G. Left G2. Scale bars: A, D, G $=0.5 \mathrm{~mm} ; \mathrm{B}-\mathrm{C}=1.0 \mathrm{~mm}$; E-F $=0.1 \mathrm{~mm}$. 
3C-D). Dactylus with 1 distinct low, longitudinal ridge, 1 submedian groove; upper margin with 2-4 spines on proximal half, cutting edge with 2 larger teeth on proximal half, distal half with 2 or 3 low teeth; tip subspatuliform (Figs 2C-D, 3C-D).

Ambulatory legs short, stout; second pair longest; fourth pair shortest (Figs 1, 3A). Basis-ischium lined with small granules. Outer surfaces of merus, carpus and propodus covered with sharp tubercles or granules (Figs 1, 2A, 3A, 4C). Merus with dorsal margin armed with numerous sharp spines which gradually become smaller proximally, distal one largest; ventral margin lined with small, sharp granules (Figs 1, 2A, 3A, 4C). Dorsal margins of carpus and propodus with several sharp spines; ventral margin of carpus with sharp granules; ventral margin of propodus with sharp spines (Figs 1, 2A, 3A, 4C). Dactylus gently curved, surface covered with small, sharp granules; ventral margin with relatively larger subterminal tubercle; tip corneous; surfaces with scattered long, simple setae, those on second to third legs may be very long, extending well beyond tip of dactylus (Figs 1, 2A, 3A, 4C). Dactylo-propodal lock well developed; distal margin of propodus with rounded median projection that overlaps ball-like swelling on proximal margin of dactylus (Fig. 4C).

Thoracic sternum with surface distinctly pitted (Figs 1B, 5B). Thoracic sternites 1 and 2 completely fused; sternites 2 and 3 separated by distinct transverse suture; sternites 3 and 4 completely fused except for lateral cleft (Figs 1B, 5B). Sternoabdominal cavity deep, reaching to median part of sternite 4 (Figs 1B, 5C). Male abdominal locking mechanism a knob-like process, on anterior third of sternite 5.

Male abdomen longitudinally narrow; surfaces of sternites $1-5$ pitted (Fig. 5C). Somites 1 and 2 trapezoidal, completely covering surfaces of thoracic sternum between coxae of last pair of ambulatory legs, sternite 8 completely covered; somites 3-5 completely fused, median sutures not discernible; lateral margins concave; somite 6 rectangular, lateral margins gently sinuous, slightly longer than telson; telson triangular, lateral margins gently sinuous, tip rounded (Fig. 5C).

G1 elongate, gently sinuous, distal part curves upwards, subdistal surfaces with numerous long setae and spinules (Fig. 5D-F). G2 short, c. quarter of length of G1; proximal part sinuous, distal part spatuliform (Fig. 5G).

\section{Females and variation}

The females agree with the males in almost all non-sexual characters. A female measuring $6.7 \times 4.9 \mathrm{~mm}$ (MNHN IU 2013-759) is still immature, with the abdomen triangular in shape. An adult female, $10.2 \times$ $7.8 \mathrm{~mm}$ (pleopods fully setose, ZRC, ex MNHN IU 2013-1245), has an ovate abdomen that covers about half the surface of the thoracic sternum. The vulvae are small, positioned on the anterior half of sternite 6 submedially and each has a distinct opercular cover in the form of a narrow plate (Fig. 4B). There is hardly any variation in the diagnostic characters, although some of the specimens (e.g., ZRC, ex MNHN IU 2013-1245) are twice the size of the smaller crabs (e.g., ZRC, ex MNHN IU 2013-920).

The long, simple setae on the ambulatory legs are easily broken, and while obvious in fresh specimens (Fig. 1), they are often lost in preserved material. The holotype male has a developed G1 (Fig. 5D-F) but does not appear to be fully mature. While the setae on the subdistal part of the G1 are long (Fig. 5E-F), they are simple and not plumose as is typical for actaeine gonopods (cf. Guinot 1976).

\section{Colour}

In life (Fig. 1), the colour is a striking bright orange to red across the median part of the carapace, with the lateral regions white. There may be patches of white on the gastric and adjacent regions in smaller specimens. The legs are banded red and white, and the chelipeds are red and white, with parts yellowishwhite in colour. The fingers of the chela are reddish-orange basally and white at the tips. The ventral surfaces are white, but abdominal somites 1 and 2 may have large patches of red. 


\section{Distribution}

This species is known for certain from the Moluccas and Papua New Guinea, and is probably also present in Australia.

\section{Discussion}

There are a group of Actaea species which have numerous small and large spines on their dorsal carapace surface, chelipeds and/or legs: $A$. calculosa (H. Milne Edwards, 1834) (=Euxanthus tuberculosus Miers, 1884), A. catalai Guinot, 1976, A. flosculata Alcock, 1898, A. fragifera (White, 1848), A. glandifera Rathbun, 1914, A. hystrix Miers, 1886, A. occidentalis Odhner, 1925, A. peronii (H. Milne Edwards, 1834), A. perspinosa Borradaile, 1902, A. petalifera Odhner, 1925, A. polyacantha (Heller, 1861) (= Xantho spinosus Hess, 1865), A. spinosissima Borradaile, 1902, and A. squamulosa Odhner, 1925 (see Guinot 1976: pls 12-14; Serène 1984: pl. 14D-F).

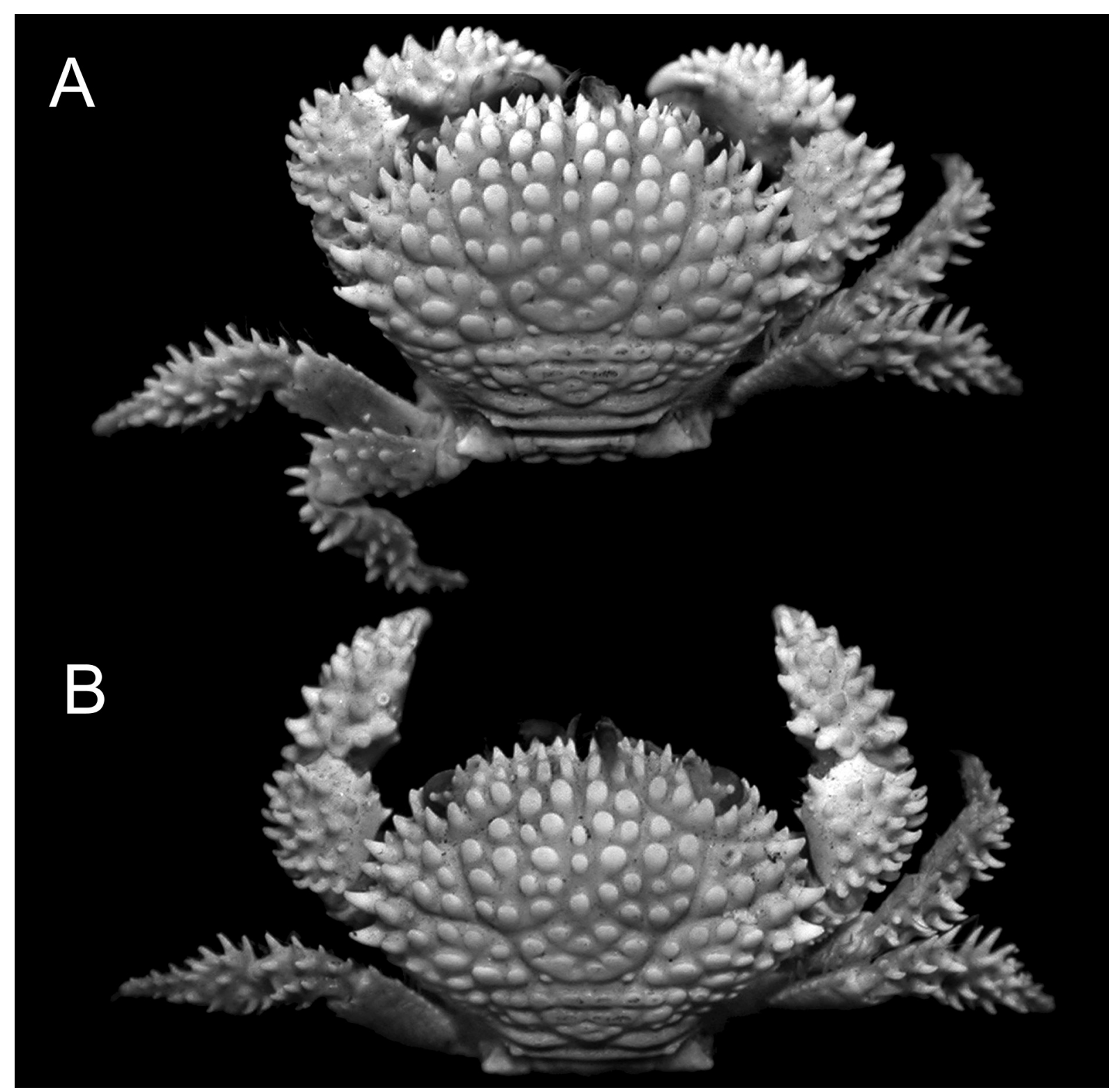

Fig. 6. Actaea spinosissima Borradaile, 1902, holotype, §̊, $5.1 \times 3.4$ mm (CUMZ I.63106). Dorsal view of habitus, photographed from slightly different angles. 
The present new species, however, has distinct anterolateral spines (not granulated or spiniform lobes), a character shared only with A. flosculata, A. fragifera, A. glandifera, A. perspinosa, A. polyacantha, A. spinosissima and A. squamulosa (cf. Guinot 1976: pl. 13, figs 2, 4-7, pl. 14, fig. 3). Actaea squamulosa is distinctive in that it has short anteorolateral spines and only low granules and rugosities on the dorsal carapace surface, and has very stout cheliped fingers (Guinot 1976: pl. 13, figs 7-8). As to the 1L, 3L and $4 \mathrm{~L}$ of the carapace possessing sharp spines, the new species shares this character with $A$. glandifera, A. perspinosa, A. polyacantha and A. spinosissima.

With regard to the general carapace facies and armature, A. grimaldii sp. nov. is most similar to A. polyacantha (cf. Guinot 1976: pl. 13, fig. 6) and A. spinosissima (cf. Borradaile 1902: fig. 55; Odhner 1925: pl. 4, fig. 4; present Figs 5-6). Actaea polyacantha, however, has the granules on 1M, 2M and 3M flattened, low and rounded (cf. Guinot 1976: pl. 13 fig. 6); these areas have spiniform granules and spines in A. grimaldii sp. nov. In addition, their G1 structures are quite different. The distal part of the G1 in A. polyacantha is formed into a pronounced lobe (Guinot 1976: fig. 40B, b) but in A. grimaldii sp. nov., the distal part of the G1 is turned upwards and tapers gradually to a sharp tip (Fig. 5E-F).

The identity of A. spinosissima Borradaile, 1902 is more problematic and its G1 structure has not been figured before. Actaea spinosissima s. str. is now known for certain only from the western Indian

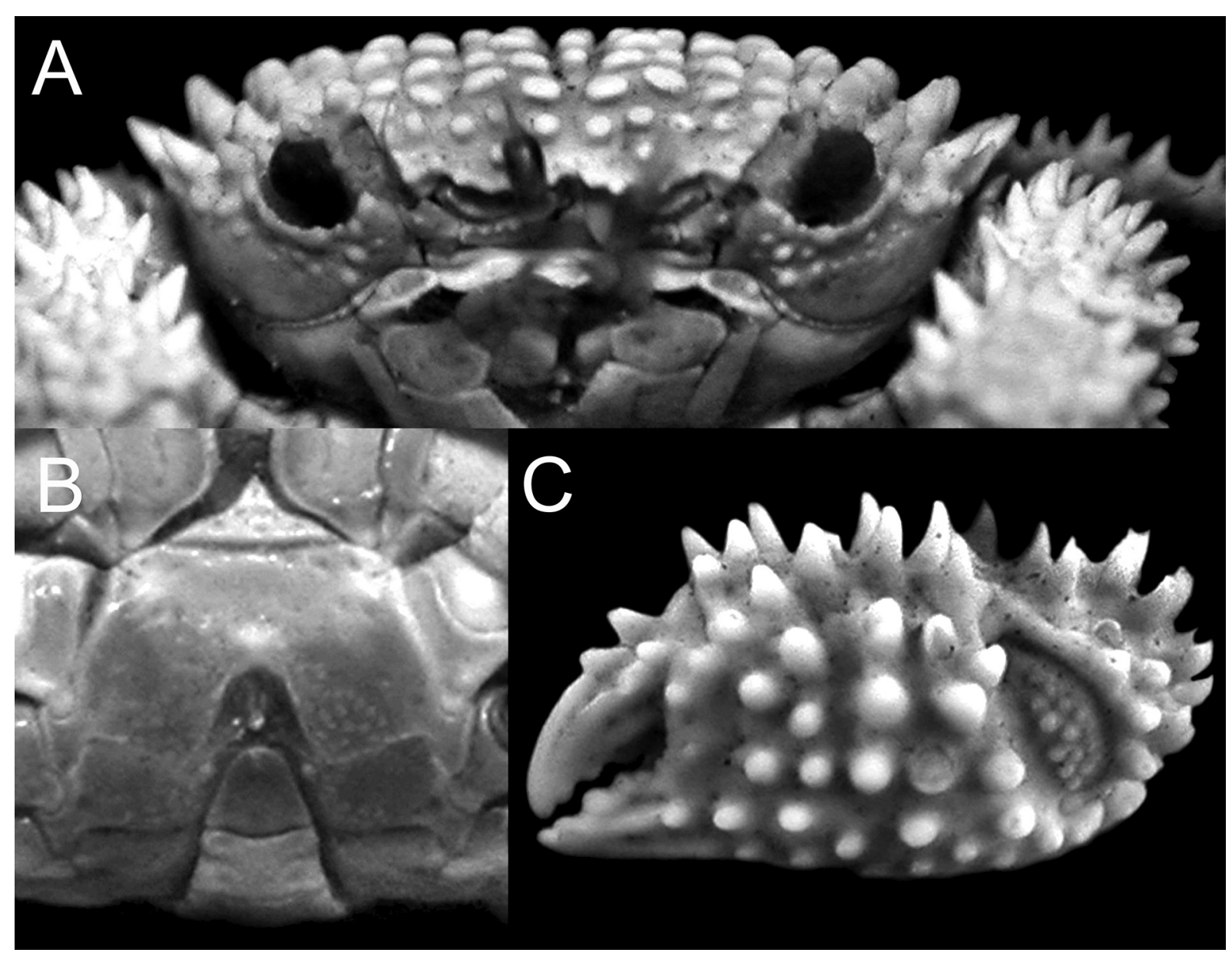

Fig. 7. Actaea spinosissima Borradaile, 1902, holotype, đ̃, $5.1 \times 3.4 \mathrm{~mm}$ (CUMZ I.63106), Maldives. A. Frontal view of carapace. B. Anterior thoracic sternum (sternites 1-4), telson and abdominal somite 6 . C. Outer view of left chela. 


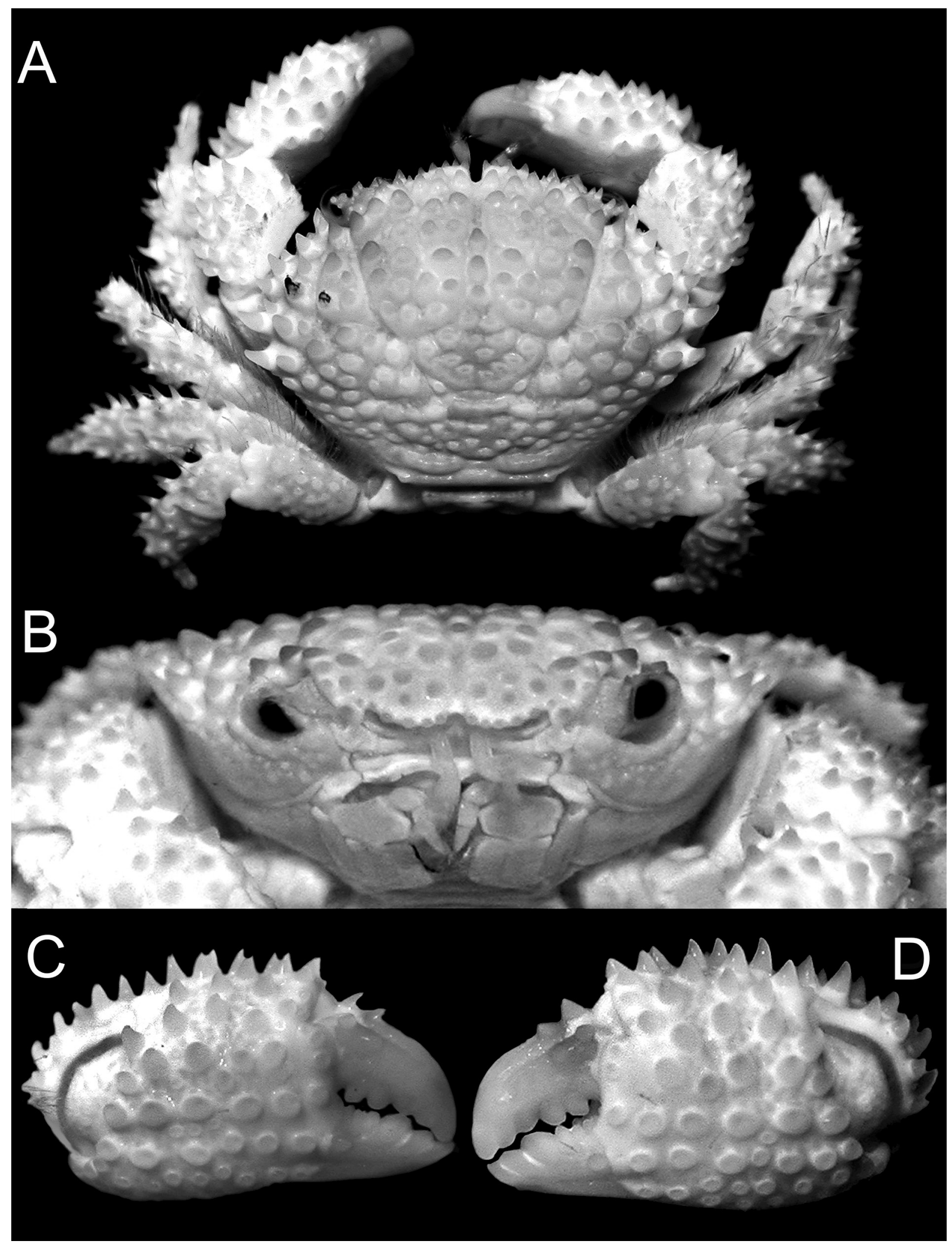

Fig. 8. Actaea spinosissima Borradaile, 1902, ô, $8.9 \times 6.6 \mathrm{~mm}($ ZRC), Chagos Islands A. Dorsal view of habitus. B. Frontal view of carapace. C. Outer view of right chela. D. Outer view of left chela. 
Ocean. Described from the Maldives by Borradaile (1902: 256, fig. 55), it was recorded again shortly after that by Rathbun (1902: 128) who also found two juveniles from these islands. Rathbun (1911) subseqently recorded another juvenile female from Cargados Carajos islands in Mauritius in the western Indian Ocean, but provided no figures. Serène (1984: 114) noted that the record of a male specimen of "A. spinosissima" from St. Brandon in Mauritius by Ward (1942: 87) is A. polyacantha instead. Whether this also includes Rathbun's (1911) specimens cannot be ascertained. The other records of

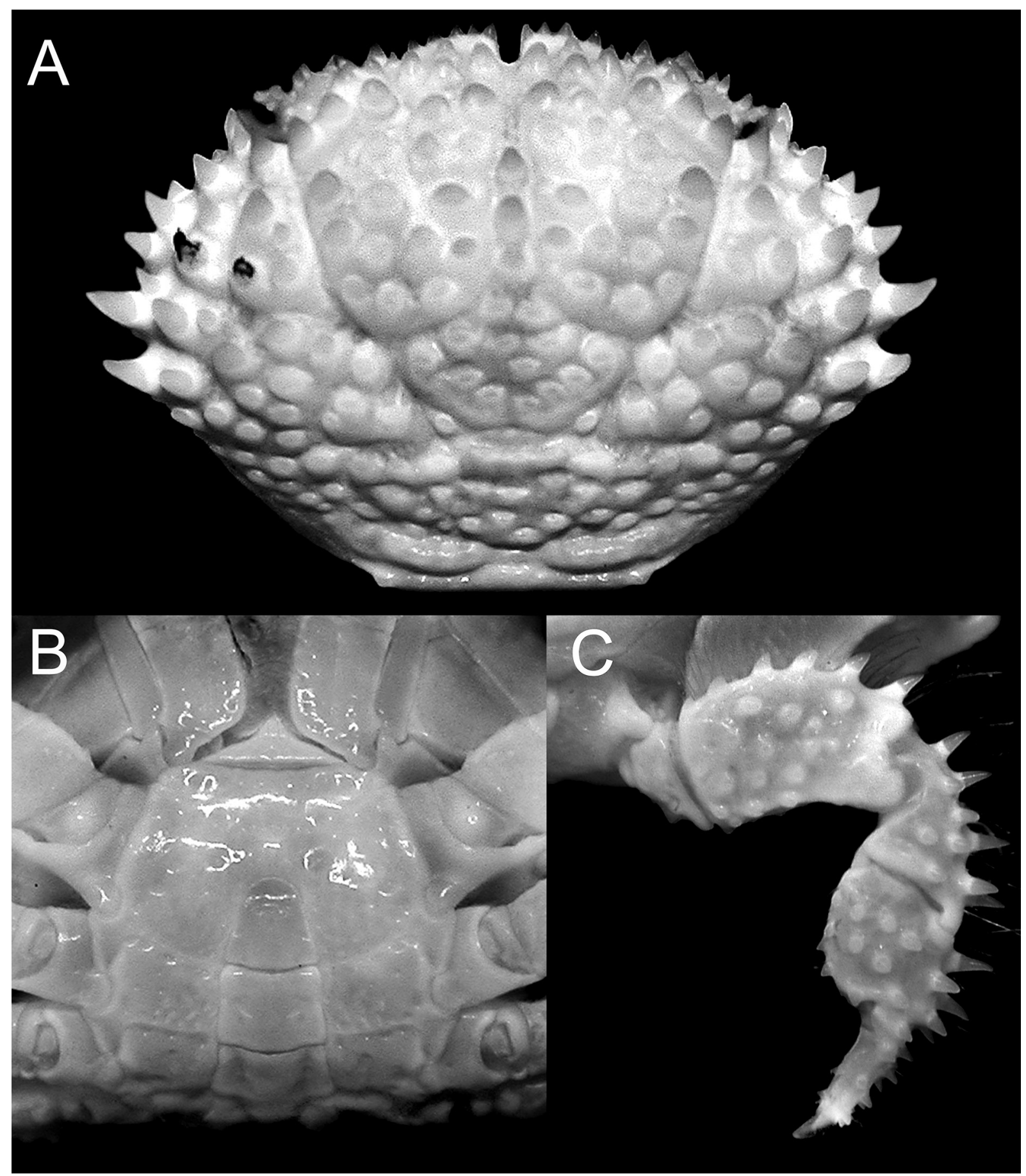

Fig. 9. Actaea spinosissima Borradaile, 1902, đ̄, $8.9 \times 6.6 \mathrm{~mm}($ ZRC), Chagos Islands A. Dorsal view of carapace. B. Thoracic sternum showing vulvae. C. Right fourth ambulatory leg. 
this species by Odhner (1925: 59, pl. 4, fig. 4), Serène (1961: 206, 1968: 79), Guinot (1967: 559, 1969 : 238, 1971: 1071, 1976: 233, pl. 13, fig. 3) and $\mathrm{Ng}$ et al. (2008: 195) merely list or discuss the species and do not record fresh material. Fortunately, among recent material examined from the Chagos Islands in the western Indian Ocean is an adult male (Figs 8-9) that agrees well with the holotype male of A. spinosissima; its G1 is figured here (Fig. 10). Although the specimen is slightly faded, the remaining colour and pattern suggest they are similar to those of $A$. grimaldii sp. nov.

The specimen figured as " $A$. spinosissima" by Serène (1984: 115, pl. 14F) (a male $6.0 \times 4.6 \mathrm{~mm}$ from Moluccas) agrees well, even in the colour and pattern (cf. Fig. 1), with what is described as A. grimaldii sp. nov. and they appear to be conspecific. Calman (1900: 10) recorded a male specimen measuring 14.0 by $10.0 \mathrm{~mm}$ that he provisionally attributed to "Actaea peronii var. squamosa" and noted as differing from A. peronii by its sharp and spiniform anterolateral teeth. Odhner (1925: 59) and Serène (1984: 114) suggested that his record was probably A. spinosissima, but could not be sure as he did not have the specimen and Calman did not figure the species. Davie (2002: 511) accepted Serène's identification and listed this species from Australia. On the basis of geography, it seems Calman's specimen is more likely to belong to $A$. grimaldii sp. nov. than to A. spinosissima s. str.
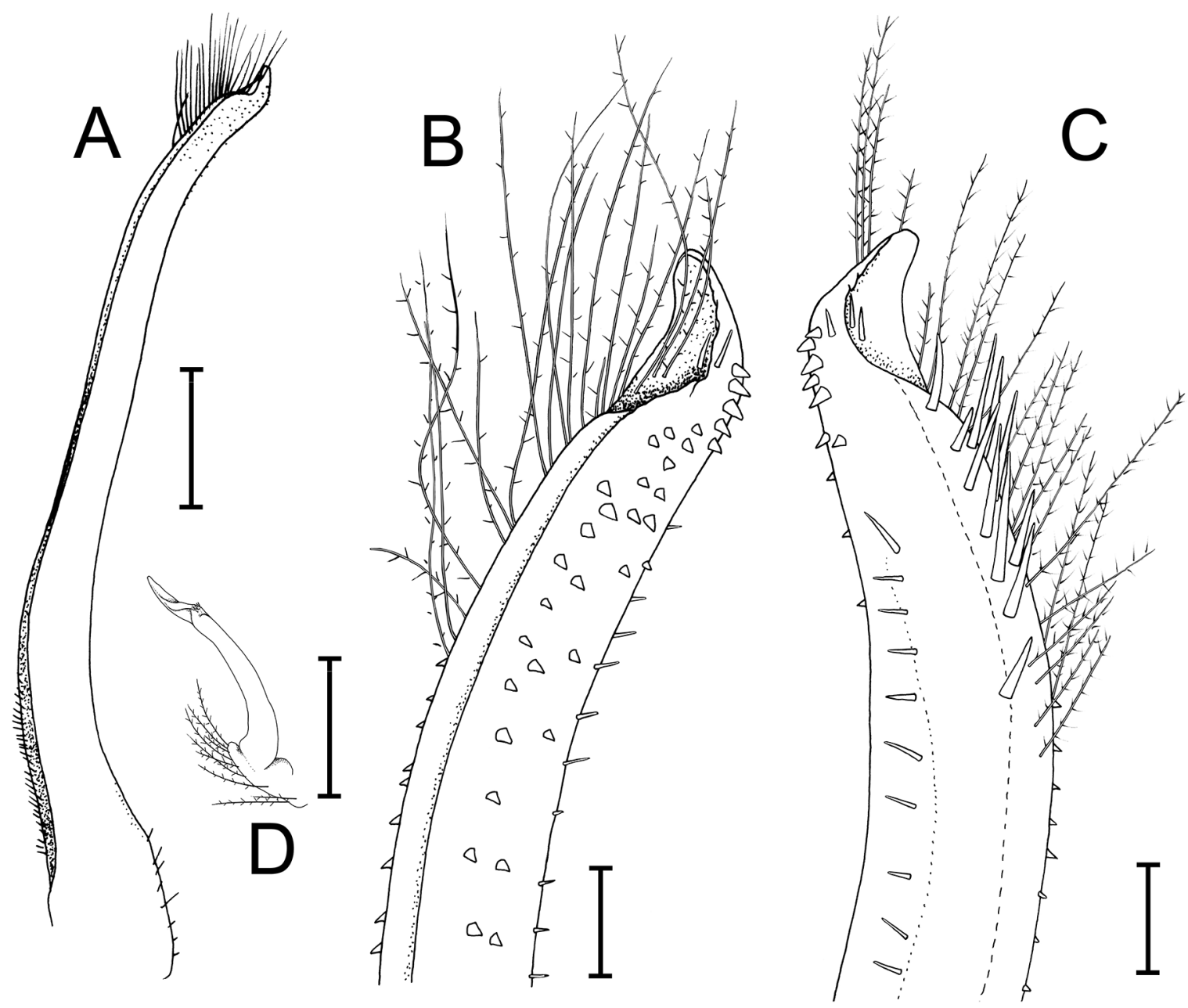

Fig. 10. Actaea spinosissima Borradaile, 1902, đo, $8.9 \times 6.6 \mathrm{~mm}($ ZRC), Chagos Islands A. Ventral view of left G1. B. Ventral view of distal part of left G1. C. Dorsal view of distal part of left G1. D. Left G2. Scale bars: A, D $=0.5 \mathrm{~mm} ; \mathrm{B}-\mathrm{C}=0.1 \mathrm{~mm}$. 
Actaea grimaldii sp. nov. differs from the type of A. spinosissima s. str. in several key characters: the granules on 1M, 2M, 3M, 2L and 5L are conical and sharp (Figs 1, 2A, 3A, 4A) (vs granules raised but tips broad and rounded in A. spinosissima, Fig. 6); the 1P and tranverse granules adjacent to it are raised and rounded (Figs 1, 2A, 3A, 4A) (vs area and granules distinctly flattened in A. spinosissima, Fig. 6); 2P is raised and rounded (Figs 1, 2A, 3A, 4A) (vs area flattened in A. spinosissima, Fig. 6); the surfaces of $2 \mathrm{M}$ and $2 \mathrm{~L}$ are gently convex (Figs $2 \mathrm{~B}, 3 \mathrm{~B}$ ) (vs areas distinctly more inflated in A. spinosissima, Fig. 7A); the subhepatic and suborbital regions are covered with numerous granules (Figs 2B, 3B) (vs these regions are covered with relatively fewer and lower granules in A. spinosissima, Figs 7A, 8B), the spines on the anterolateral margin and carpus of cheliped acute and straight or gently curved (Figs 1,2A, 3A) (vs spines relatively stouter and more distinctly curved anteriorly in A. spinosissima, Fig. 6); the spines on the chela are relatively slender (Figs 2C, D, 3C, D) (vs stouter in A. spinosissima, Fig. 7C); the ambulatory merus is proportionately longer (Figs 2A, 3B, 4C) (vs distinctly shorter in A. spinosissima, Figs 6, 8A, 9C); and the G1 is proportionately stouter (Fig. 5D) (vs more slender in A. spinosissima, Fig. 10A).

\section{Acknowledgements}

The "Our Planet Reviewed" PAPUA NUIGINI Expedition was organized by MNHN (marine Principal Investigators: Philippe Bouchet, Claude Payri and Sarah Samadi), Pro Natura International, and Institut de Recherche pour le Développement, in partnership with University of Papua New Guinea; with funding and support from the Prince Albert II of Monaco Foundation, Total Foundation, Foundation EDF, Stavros Niarchos Foundation, Entrepose Contracting, and in-kind support from the Divine Word University; the expedition operated under a permit from the Papua New Guinea Department of Environment and Conservation. The authors thank Matthew Lowe (CUMZ) for permission to examine the type of Actaea spinosissima, and Paul Clark (The Natural History Museum, London) for facilitating the loan. The colour photographs are courtesy of Tin-Yam Chan (National Taiwan Ocean University) and Arthur Anker (National University of Singapore). Thanks are also due to Danièle Guinot (MNHN) and several anonymous reviewers for their helpful comments on the manuscript.

\section{References}

Borradaile L.A. 1902. Marine crustaceans III: The Xanthidae and some other crabs. In: Gardiner J.S. (ed.) The Fauna and Geography of the Maldive and Laccadive Archipelagoes, being the Account of the Work carried on and of the Collections made by an Expedition during the Years 1899 and 1900. Vol. 1. Part. 3: 237-271. Cambridge University Press, Cambridge. http://dx.doi.org/10.5962/bhl.title.10215

Calman W.T. 1900. On a collection of Brachyura from Torres Straits. Transactions of the Linnean Society of London, Zoology, series 28 (1): 1-50. http://dx.doi.org/10.1111/j.1096-3642.1900.tb00307.x

Dana J.D. 1852. United States Exploring Expedition during the Years 1838, 1839, 1840, 1841, 1842, under the Command of Charles Wilkes, U.S.N. Vol. 13. Crustacea. Part 1. C. Sherman, Philadelphia. http://dx.doi.org/10.5962/bhl.title.69333

Davie P.J.F. 2002. Crustacea: Malacostraca. Eucarida. Part 2. Decapoda-Anomura, Brachyura. Zoological Catalogue of Australia 19.3B, CSIRO Publications, Collingwood.

Fricke R. 2014. Callionymus madangensis, a new species of dragonet from Papua New Guinea, southwestern Pacific Ocean (Teleostei: Callionymidae). Journal of the Ocean Science Foundation 13: 1-15.

Gosliner T.M. 1992. Biodiversity of tropical opisthobranch gastropod faunas. In: Richmond R.H. (ed.) Proceedings of the Seventh International Coral Reef Symposium, Guam. Vol. 2: 702-709. University of Guam Press, UOG Station, Guam. 
Guinot D. 1967. Recherches préliminaires sur les groupements naturels chez les Crustacés Décapodes Brachyoures. III. A propos des affinités des genres Dairoides Stebbing et Daira de Haan. Bulletin du Muséum national d'Histoire naturelle, série 239 (3): 540-563.

Guinot D. 1968 [1967]. Recherches préliminaires sur les groupements naturels chez les Crustacés Décapodes Brachyoures. IV. Observations sur quelques genres de Xanthidae. Bulletin du Muséum national d'Histoire naturelle, série 239 (4): 695-727.

Guinot D. 1969. Sur divers Xanthidae, notamment sur Actaea de Haan et Paractaea gen. nov. (Crustacea Decapoda Brachyura). Cahiers du Pacifique 13: 223-267.

Guinot D. 1971 [1970]. Recherches préliminaires sur les groupements naturels chez les Crustacés Décapodes Brachyoures. VIII. Synthèse et bibliographie. Bulletin du Muséum national d'Histoire naturelle, série 242 (5): 1063-1090.

Guinot D. 1976. Constitution de quelques groupes naturels chez les Crustacés Décapodes Brachyoures. I. La superfamille des Bellioidea et trois sous-familles de Xanthidae (Polydectinae Dana, Trichiinae de Haan, Actaeinae Alcock). Mémoires du Muséum national d'Histoire naturelle, Série A 97, Muséum national d'Histoire naturelle, Paris.

Guinot D. \& Cleva R. 2009. Nouvelles explications des planches de "Crustacés Décapodes" de la Description de l'Égypte (planches 1 à 10) dessinées sous la direction de Jules-César Savigny et commentées sommairement à l'origine par Victor Audouin, et explication des espèces inédites de Crustacés figurant dans l' "Atlas d'Histoire naturelle" de Savigny (volume 4, planches 52, 54, 61 à 66), accompagnées de précisions et commentaires scientifiques et historiques. Nouvelle Description de l'Égypte, Institut d'Orient, Paris.

Guinot D. \& Low M.E.Y. 2010. Forestiana nom. nov., a replacement name for Forestia Guinot, 1976 (Crustacea: Brachyura: Xanthidae), pre-occupied by Forestia Trinchese, 1881 (Mollusca: Calmidae: Nudibranchia). Zootaxa 2489: 67-68.

Klunzinger C.B. 1913. Die Rundkrabben (Cyclometopa) des Roten Meeres. Nova Acta Abhandlungen der Kaiserlich Leop.-Carol. Deutschen Akademie der Naturforscher 99 (2): 97-402. http://dx.doi. org/10.5962/bhl.title.13073

Macpherson E. \& Robainas-Barcia A. 2015. Species of the genus Galathea Fabricius, 1793 (Crustacea, Decapoda, Galatheidae) from the Indian and Pacific Oceans, with descriptions of 92 new species. Zootaxa 3913: 1-335. http://dx.doi.org/10.11646/zootaxa.3913.1.1

Meyer-Wachsmuth I., Curini Galletti M. \& Jondelius U. 2014. Hyper-cryptic marine meiofauna: Species complexes in Nemertodermatida. PLoS ONE 9 (9): e107688. http://dx.doi.org/10.1371/journal. pone. 0107688

Ng P.K.L. \& Anker A. 2014. Pteromaja maklayi gen. et sp. nov., a remarkable new spider crab (Crustacea: Brachyura: Epialtidae) from Papua New Guinea. Marine Biology Research 10 (8): 816-823. http:// dx.doi.org/10.1080/17451000.2013.853127

Ng P.K.L., Guinot D. \& Davie P.J.F. 2008. Systema Brachyurorum: Part I. An annotated checklist of extant brachyuran crabs of the world. Raffles Bulletin of Zoology supplement 17: 1-286.

Odhner T. 1925. Monographierte Gattungen der Krabbenfamilie Xanthidae. I. Göteborgs Kungliga Vetenskaps-och Vitterhets-Samhälles Handlingar, serie 429 (1): 1-92.

Rathbun M.J. 1902. Crabs from the Maldive Islands. Bulletin of the Museum of Comparative Zoölogy 39 (5): 123-138. 
Rathbun M.J. 1911. XI. Marine Brachyura. In: The Percy Sladen Trust Expedition to the Indian Ocean in 1905, under the Leadership of Mr. J. Stanley Gardiner. Vol. III. Transactions of the Linnean Society of London, Zoology, series 214 (2): 191-261.

Rubio F. \& Rolán E. 2014. The family Tornidae in the tropical Southwest Pacific: the genus Anticlimax Pilsbry \& McGinty, 1946 (Gastropoda, Truncatelloidea) with the description of 42 new species. Iberus supplement 6: 1-126.

Serène R. 1961. Les espèces Indo-Pacifique d'Actea et celles des genres Pseudactea et Banareia. Bulletin de la Société Zoologique de France 86: 195-212.

Serène R. 1968. The Brachyura of the Indo-West Pacific Region. In: Prodromus for a Check List of the (non-planctonic) Marine Fauna of South East Asia: 33-112. Singapore National Academy of Sciences, Special Publication 1, Singapore.

Serène R. 1984. Crustacés Décapodes Brachyoures de l'Océan Indien occidental et de la Mer Rouge. Xanthoidea: Xanthidae et Trapeziidae. Addendum: Crosnier A. Carpiliidae et Menippidae. Faune Tropicale 24, Éditions de l'ORSTOM, Paris.

Summers M.M., Al-Hakim I.I. \& Rouse G.W. 2014. Turbo-taxonomy: 21 new species of Myzostomida (Annelida). Zootaxa 3873 (4): 301-344. http://dx.doi.org/10.11646/zootaxa.3873.4.1

Thomas J.D. 1996. Using marine invertebrates to establish research and conservation priorities. In: Reaka-Kudla M.L., Wilson D.E. \& Wilson E.O. (eds) Biodiversity II: Understanding and Protecting our Biological Resources: 357-388. National Academy Press, Washington.

Ward M. 1942. Notes on the Crustacea of the Desjardins Museum, Mauritius Institute, with descriptions of new genera and species. Bulletin of the Mauritius Institute 2 (2): 49-113.

Manuscript received: 25 May 2015

Manuscript accepted: 10 September 2015

Published on: 29 September 2015

Topic editor: Rudy Jocqué

Desk editor: Charlotte Thionois

Printed versions of all papers are also deposited in the libraries of the institutes that are members of the EJT consortium: Muséum national d'Histoire naturelle, Paris, France; Botanic Garden Meise, Belgium; Royal Museum for Central Africa, Tervuren, Belgium; Natural History Museum, London, United Kingdom; Royal Belgian Institute of Natural Sciences, Brussels, Belgium; Natural History Museum of Denmark, Copenhagen, Denmark. 